\title{
Front Matter: Volume 6768
}

, "Front Matter: Volume 6768," Proc. SPIE 6768, Nanomaterials Synthesis, Interfacing, and Integrating in Devices, Circuits, and Systems II, 676801 (15 October 2007); doi: 10.1117/12.779769

SPIE. Event: Optics East, 2007, Boston, MA, United States 


\title{
PROCEEDINGS OF SPIE
}

\section{Nanomaterials Synthesis, Interfacing, and Integrating in Devices, Circuits, and Systems II}

\author{
Nibir K. Dhar \\ Achyut K. Dutta \\ M. Saif Islam \\ Editors
}

9 and 11 September 2007

Boston, Massachusetts, USA

Sponsored and Published by

SPIE 
The papers included in this volume were part of the technical conference cited on the cover and title page. Papers were selected and subject to review by the editors and conference program committee. Some conference presentations may not be available for publication. The papers published in these proceedings reflect the work and thoughts of the authors and are published herein as submitted. The publisher is not responsible for the validity of the information or for any outcomes resulting from reliance thereon.

Please use the following format to cite material from this book:

Author(s), "Title of Paper," in Nanomaterials Synthesis, Interfacing, and Integrating in Devices, Circuits, and Systems II, edited by Nibir K. Dhar, Achyut K. Dutta, M. Saif Islam, Proceedings of SPIE Vol. 6768 (SPIE, Bellingham, WA, 2007) Article CID Number.

ISSN 0277-786X

ISBN 9780819469281

Published by

SPIE

P.O. Box 10, Bellingham, Washington 98227-0010 USA

Telephone +1 3606763290 (Pacific Time) · Fax +1 3606471445

SPIE.org

Copyright (c) 2007, Society of Photo-Optical Instrumentation Engineers

Copying of material in this book for internal or personal use, or for the internal or personal use of specific clients, beyond the fair use provisions granted by the U.S. Copyright Law is authorized by SPIE subject to payment of copying fees. The Transactional Reporting Service base fee for this volume is $\$ 18.00$ per article (or portion thereof), which should be paid directly to the Copyright Clearance Center (CCC), 222 Rosewood Drive, Danvers, MA 01923. Payment may also be made electronically through CCC Online at copyright.com. Other copying for republication, resale, advertising or promotion, or any form of systematic or multiple reproduction of any material in this book is prohibited except with permission in writing from the publisher. The CCC fee code is $0277-786 \mathrm{X} / 07 / \$ 18.00$.

Printed in the United States of America.

Publication of record for individual papers is online in the SPIE Digital Library.

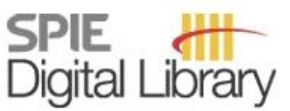

SPIEDigitalLibrary.org

Paper Numbering: Proceedings of SPIE follow an e-First publication model, with papers published first online and then in print and on CD-ROM. Papers are published as they are submitted and meet publication criteria. A unique, consistent, permanent citation identifier (CID) number is assigned to each article at the time of the first publication. Utilization of CIDs allows articles to be fully citable as soon they are published online, and connects the same identifier to all online, print, and electronic versions of the publication. SPIE uses a six-digit CID article numbering system in which:

- The first four digits correspond to the SPIE volume number.

- The last two digits indicate publication order within the volume using a Base 36 numbering system employing both numerals and letters. These two-number sets start with 00, 01, 02, 03, 04, 05, $06,07,08,09,0 \mathrm{~A}, 0 \mathrm{~B} \ldots \mathrm{OZ}$, followed by $10-1 \mathrm{Z}, 20-2 \mathrm{Z}$, etc.

The CID number appears on each page of the manuscript. The complete citation is used on the first page, and an abbreviated version on subsequent pages. Numbers in the index correspond to the last two digits of the six-digit CID number. 


\section{Contents}

vii Conference Committee

SYNTHESIS, PROPERTIES, DOPING, AND CHARACTERIZATION OF NANOWIRES I

676802 Dielectric and geometric properties of plasmonics in metal/dielectric nanowires composites used in surface-enhanced Raman spectroscopy [6768-01]

O. J. Glembocki, R. W. Rendell, S. M. Prokes, D. A. Alexson, M. A. Mastro, S. C. Badescu, Naval Research Lab. (USA); A. FU, Univ. of Maryland, College Park (USA)

676803 A review of growth and characterization of $\mathrm{ZnO}$ nanostructures for various optical applications [6768-02]

A. K. Sood, Y. R. Puri, Magnolia Optical Technologies, Inc. (USA); C. Lao, W. Mai, P. Gao, S. XU, Z. L. Wang, Georgia Institute of Technology (USA); D. L. Polla, M. B. Soprano, DARPA (USA); N. K. Dhar, Army Research Lab. (USA)

676804 Growth kinetics of InP nanowires heteroepitaxially grown on a silicon surface [6768-03] A. Sarkar, I. Kimukin, C. W. Edgar, Univ. of California, Davis (USA); S. Yi, Agilent Technologies (USA); C. Mitterbauer, N. Browning, M. S. Islam, Univ. of California, Davis (USA)

676806 Dual contribution of FIIR spectroscopy to nanoparticles characterization: surface chemistry and electrical properties (Invited Paper) [6768-05]

M.-I. Baraton, SPCTS-CNRS, Univ. de Limoges (France); L. Merhari, CERAMEC R\&D (France)

676807 Characterization of nanoparticles by computer imaging particle analysis [6768-28]

J. DaPonte, T. Sadowski, C. C. Broadbridge, P. Munhutu, Southern Connecticut State Univ. (USA); A. Lehman, Trinity College (USA) and Southern Connecticut State Univ. (USA);

D. Krishnamoorthy, E. Garcia, M. Sawicki, C. Heyden, L. Mirabelle, P. Benjamin, Southern Connecticut State Univ. (USA)

676808 Nanocrystalline cobalt oxides for carbon nanotube growth [6768-29]

K. Guo, A. H. Jayatissa, A. C. Jayasuriya, Univ. of Toledo (USA)

676809 Properties of low-temperature grown carbon nanotubes [6768-30]

K. Guo, A. H. Jayatissa, Univ. of Toledo (USA)

6768 0A Diameter distribution of thermally evaporated indium metal islands on silicon substrates [6768-32]

J. Balch, L. Tsakalakos, W. Huber, J. Grande, M. Knussman, General Electric Global

Research Ctr. (USA); T. S. Cale, Rensselaer Polytechnic Institute (USA) 
6768 OD Numerical studies of semiconductor nanowire electrostatics (Invited Paper) [6768-06]

D. R. Khanal, J. WU, Univ. of California, Berkeley (USA) and Lawrence Berkeley National Lab. (USA)

$6768 \mathrm{OE}$ Formation of ordered and disordered dielectric/metal nanowire arrays and their plasmonic behavior [6768-07]

S. M. Prokes, H. D. Park, O. J. Glembocki, D. Alexson, R. W. Rendell, Naval Research Lab. (USA)

6768 OF Understanding the unusual conduction mechanism in InN nanowires [6768-08]

A. Chaudhry, M. S. Islam, Univ. of California, Davis (USA)

\section{NANODEVICES FOR ELECTRONICS, PHOTONICS, AND ENERGY APPLICATIONS I}

6768 Ol Nanostructure and molecular interface for biosensing devices (Invited Paper) [6768-11] H. M. Hiep, Japan Advanced Institute of Science and Technology (Japan); T. Endo, Tokyo Institute of Technology (Japan); D.-K. Kim, E. Tamiya, Osaka Univ. (Japan)

6768 OK Field emission properties of carbon nanosphere chain arrays self-assembled on porous alumina templates (Invited Paper) [6768-14]

M. Cahay, K. Garre, Univ. of Cincinnati (USA); J. W. Fraser, D. J. Lockwood, National Research Council (Canada); V. Semet, V. T. Binh, LPMCN, CNRS, Univ. de Lyon 1 (France);

S. Pramanik, B. Kanchibotla, S. Bandyopadhyay, Virginia Commonwealth Univ. (USA)

6768 ON Individual SWNT based thermoelectric power chemical sensors [6768-31]

S. C. Desai, K. P. Hewaparakrama, G. U. Sumanasekera, Univ. of Louisville (USA);

A. H. Jayatissa, Univ. of Toledo (USA)

\section{NANODEVICES FOR ELECTRONICS, PHOTONICS, AND ENERGY APPLICATIONS II}

6768 OP Persistent photoconductivity of InP nanowire photoconductors bridged between amorphous silicon electrodes [6768-18]

A. Sarkar, L. V. J., Univ. of California, Davis (USA); N. P. Kobayashi, Univ. of California, Santa Cruz (USA); J. Straznicky, S.-Y. Wang, R. S. Williams, Hewlett-Packard Labs. (USA); M. S. Islam, Univ. of California, Davis (USA)

6768 OS The role of surface adsorption in surface-enhanced Raman scattering from Benzene thiols (Invited Paper) [6768-21]

D. A. Alexson, O. J. Glembocki, S. M. Prokes, R. W. Rendell, S. C. Badescu, Naval Research Lab. (USA); J. Onuegbu, C. M. Hosten, Howard Univ. (USA)

6768 OT Nanoscopic building blocks from polymers, metals, and semiconductors (Invited Paper) [6768-22]

W. Knoll, P. Cameron, A. M. Caminade, C. L. Feng, D. H. Kim, M. Kreiter, J.-P. Majoral, K. Müllen, H. Rocholz, J. Shumaker-Parry, M. Steinhart, X. Zhong, Max Planck Institute for Polymer Research (Germany) 
SPECIAL SESSION ON OPPORTUNITIES IN NANOTECHNOLOGY I: JOINT SESSION WITH CONFERENCE 6769: NANOSENSING: MATERIALS, DEVICES, AND SYSTEMS III AND CONFERENCE 6779: NANOPHOTONICS FOR COMMUNICATION: MATERIALS, DEVICES, AND SYSTEMS IV

6768 OU A new route to grow single-crystal group III-V compound semiconductor nanostructures on non-single-crystal substrates (Invited Paper) [6768-23]

N. P. Kobayashi, Univ. of California, Santa Cruz (USA) and Hewlett-Packard Labs. (USA)

SPECIAL SESSION ON OPPORTUNITIES IN NANOTECHNOLOGY II: JOINT SESSION WITH CONFERENCE 6769: NANOSENSING: MATERIALS, DEVICES, AND SYSTEMS III AND CONFERENCE 6779: NANOPHOTONICS FOR COMMUNICATION: MATERIALS, DEVICES, AND SYSTEMS IV

$67680 \mathrm{X}$ Tutorial on chip-based electrophysiology to assess ion channel function (Invited Paper) [6768-26]

H. Han, C. E. Davis, Univ. of California, Davis (USA)

6768 OY Chains of divalent gold nanoparticles (Invited Paper) [6768-27]

G. A. DeVries, A. Centrone, F. Stellacci, Massachusetts Institute of Technology (USA)

$67680 Z$ DNA-directed assembly of nanocomponents for nanoelectronics, nanophotonics, and nanosensing (Invited Paper) [6768-35]

R. A. Kiehl, Univ. of Minnesota (USA)

Author Index 
Downloaded From: https://www.spiedigitallibrary.org/conference-proceedings-of-spie on 25 Apr 2023

Terms of Use: https://www.spiedigitallibrary.org/terms-of-use 


\title{
Conference Committee
}

\author{
Symposium Chairs
}

Tuan Vo-Dinh, Duke University (USA)

Robert A. Lieberman, Intelligent Optical Systems, Inc. (USA)

\section{Conference Chairs}

Nibir K. Dhar, Army Research Laboratory (USA)

Achyut K. Dutta, Banpil Photonics, Inc. (USA)

M. Saif Islam, University of California, Davis (USA)

Program Committee

Mehdi Anwar, University of Connecticut (USA)

Jeyadevan Balachandran, Tohoku University (Japan)

Connie J. Chang-Hasnain, University of California, Berkeley (USA)

Yi Cui, Stanford University (USA)

Aykutlu Dana, Bilkent University (Turkey)

Martina Gerken, Universität Karlsruhe (Germany)

Ali Gokirmak, University of Connecticut (USA)

Supratik Guha, IBM Thomas J. Watson Research Center (USA)

Roland Harig, Technische Universität Hamburg-Harburg (Germany)

Karl-Heinz Heinig, Forschungszentrum Rossendorf (Germany)

David A. Horsley, University of California, Davis (USA)

Ali Javey, University of California, Berkeley (USA)

Song Jin, University of Wisconsin, Madison (USA)

Satoshi Kawata, Osaka University (Japan)

Savas Kaya, Ohio University (USA)

Nobuhiko P. Kobayashi, University of California, Santa Cruz (USA) and Hewlett-Packard Laboratories (USA)

Andres H. La Rosa, Portland State University (USA)

Sang Bok Lee, University of Maryland, College Park (USA)

Jia G. Lu, University of Southern California (USA)

Samuel S. Mao, Lawrence Berkeley National Laboratory (USA)

Sagi Mathai, University of California, Berkeley (USA)

Gilberto Medeiros-Ribeiro, Laboratory Nacional de Luz Sincrotron

(Brazil)

Sharka M. Prokes, Naval Research Laboratory (USA)

Loucas Tsakalakos, GE Global Research Center (USA)

Rasit Turan, Middle East Technical University (Turkey)

Ant Ural, University of Florida (USA)

Deli Wang, University of California, San Diego (USA) 
Sungsoo Yi, Philips Lumileds Lighting Company (USA)

Yuegang Zhang, Intel Corporation (USA)

Chongwu Zhou, University of Southern California (USA)

Session Chairs

Synthesis, Properties, Doping, and Characterization of Nanowires I

Andrei A. Kolmakov, Southern Illinois University, Carbondale (USA)

Aykutlu Dana, Bilkent University (Turkey)

Synthesis, Properties, Doping, and Characterization of Nanowires II

Aykutlu Dana, Bilkent University (Turkey)

Andrei A. Kolmakov, Southern Illinois University, Carbondale (USA)

Nanodevices for Electronics, Photonics, and Energy Applications I

Sharka M. Prokes, Naval Research Laboratory (USA)

Savas Kaya, Ohio University (USA)

Nanodevices for Electronics, Photonics, and Energy Applications II Savas Kaya, Ohio University (USA)

Sharka M. Prokes, Naval Research Laboratory (USA)

Special Session on Opportunities in Nanotechnology I: Joint Session with Conference 6769: Nanosensing: Materials, Devices, and Systems III and Conference 6779: Nanophotonics for Communication: Materials, Devices, and Systems IV

Cristina E. Davis, University of California, Davis (USA)

A. A. Talin, Sandia National Laboratories (USA)

Special Session on Opportunities in Nanotechnology II: Joint Session with Conference 6769: Nanosensing: Materials, Devices, and Systems III and Conference 6779: Nanophotonics for Communication:

Materials, Devices, and Systems IV

Nobuhiko P. Kobayashi, University of California, Santa Cruz (USA) and Hewlett-Packard Laboratories (USA)

M. Saif Islam, University of California, Davis (USA) 